\title{
Interest rate liberalization and pass-through of monetary policy rate to bank lending rates in China
}

\author{
Jingya Li (i) and Ming-Hua Liu
}

\author{
* Correspondence: yb57015@um. \\ edu.mo \\ Faculty of Business Administration, \\ University of Macau, Macau, China
}

\begin{abstract}
We examine whether the effectiveness of the monetary policy rate transmission differs before and after interest rate liberalization in China using the autoregressive distributed lag (ARDL) bound test and an error correction model (ECM). The results show that after liberalization the mark-up is lower, and both the long-run and shortrun interest rate pass-through has become faster and more complete. We attribute our findings to the ongoing reforms of China's banking system, which has improved the competitiveness of Chinese commercial banks.
\end{abstract}

Keywords: Interest rate pass-through, Interest rate liberalization, China, Autoregressive distributed lag (ARDL) bound test, Error correction model (ECM)

\section{Introduction}

The People's Bank of China (PBOC) started to liberalize the interest rates of commercial banks at the end of the 1990s. Prior to interest rate liberalization, both the lending and deposit rates were set by PBOC. All commercial banks charged similar interest rates on bank loans, regardless of the credit risk of their borrowers. All banks offered similar deposit rates and almost all banks, big or small, enjoyed implicit guarantees from the Chinese government. As a result, loans were often channeled to some inefficient and loss-making state-owned enterprises (SOEs) that also enjoyed implicit government guarantees. However, small- and medium-sized enterprises in the private sector had very limited access to bank loans.

The main objectives of interest rate liberalization were to give commercial banks more leeway in pricing their loans and deposits to compete with each other, improve bank efficiency, and then promote economic development. Under the old interest rate pricing mechanism, commercial banks were unwilling to bear more risks in lending to private sector firms since commercial banks could not be compensated by charging borrowers higher rates. As capital markets in China are still in the developing stage, access to bank credit is vital for economic development.

It is well known that there is a trade-off between competition and the stability of the banking system (Keeley 1990; Uhde and Heimeshoff 2009; Tabak et al. 2012; Mirzaei et al. 2013; Fu et al. 2014). Intense competition may increase the likelihood of bank failures and contagious bank runs in the absence of deposit insurance. To maintain the

(c) The Author(s). 2019 Open Access This article is distributed under the terms of the Creative Commons Attribution 4.0 International License (http://creativecommons.org/licenses/by/4.0/), which permits unrestricted use, distribution, and reproduction in any medium, provided you give appropriate credit to the original author(s) and the source, provide a link to the Creative Commons license, and indicate if changes were made. 
fine balance between competition and the safety and soundness of the entire banking system, the Chinese government adopted a very cautious approach towards the interest rate liberation.

Liberalization of retail lending rates took more than 15 years. It started in October 1998 and was completed in July 2013, while liberalization of retail deposit rates started in October 2004 and was completed in October 2015. During the different stages of liberalization, commercial banks were given more and more power to set the interest rates of their deposits and loans. After liberalization was completed, commercial banks gained full authority to set their own deposit rates and charge their customers based on borrowers' credit risks and other factors.

Interest rate liberalization typically has a huge impact on the conduct of banks and the monetary policy transmission mechanism through the banking system, i.e., the pass-through of interest rates (Tobin 1970; Lam and Chen 1985; Cottarelli et al. 1986; Mertens 2008; Koch 2015). Interest rate pass-through is affected by many factors. One of the factors is the competitiveness of the banking industry.

The structure of China's banking system is highly concentrated. The big four state-owned banks have dominated China's banking sector for decades. ${ }^{1}$ Prior to interest rate liberalization, the dominant banks could not exercise their market power to extract rents from their customers as interest rates were determined by the PBOC. All commercial banks would raise or lower the retail deposit or lending rates to almost the same level when a change in the policy rate was announced. However, as the dominant banks gained more and more power to set retail interest rates during the interest rate liberalization process, the traditional structure-conduct-performance (SCP) paradigm predicts that these banks may set less favorable prices for their customers when the industry is highly concentrated. This implies that, during the post-liberalization period, the dominant banks may raise the deposit rates slower and lending rates faster when the policy rate goes up, and/or lower their deposit rates faster and lending rates slower when the policy rate goes down, which hampers the effectiveness of monetary policy transmission.

On the other hand, the theory of contestable markets argues that if barriers to entry and exit are low, there exists a constant threat of potential entrants (Baumol 1982). In the absence of significant sunk costs and economies of scale, and with equal access to technology, the threat of entry is sufficient to make existing firms behave in a way that is consistent with a highly competitive market structure.

Based on the above considerations, the impact of interest rate liberalization on interest rate pass-through is therefore an empirical issue. In this paper, we provide empirical evidence on the pass-through of the policy rate to lending rates set by commercial banks by testing whether the effectiveness of monetary policy transmission is hampered or enhanced after interest rate liberalization in China. Specifically, we analyze the pass-through of changes in the monetary policy rate to bank lending rates in China for the pre-liberalization (January1995 to July 2013) and post liberalization (August 2013 to December 2017) periods. We use the autoregressive distributed lag (ARDL) bound test to examine whether there is a long-term relationship between monetary policy rates and bank lending rates. We then employ an error correction model (ECM) to analyze the short-term interest rate pass-through from the monetary policy rate to bank lending rates for the two sub-periods. 
The Chinese case is interesting for the following reasons: (1) Interest rates (both lending and deposit rates) of all maturities were tightly controlled by the government. Although many studies have examined the effectiveness of other channels of China's monetary policy transmission (e.g., Wong and Poon 2011; He et al. 2013; Fungáčová et al. 2016; Chen et al. 2017; Wang et al. 2017), little attention has been paid to the interest rate pass-through transmission channel. (2) Unlike the central banks in some other countries, the central bank in China is not independent. Furthermore, the four state-owned banks play a dominant role in the banking system. (3) Monetary policy in China is very different from those in other countries. In Western countries, before unconventional monetary policies were adopted, central banks typically set the overnight policy rate, e.g., the Federal Fund rate in the US. In response to changes in the policy rates, commercial banks adjust their deposit rates and lending rates of longer maturities. Monetary policies in the West typically have more direct and immediate impact on the short end of the yield curve. After the outbreak of the 2008 Global Financial Crisis, some countries embarked on various forms of unconventional monetary policies. For example, in the US, the UK, Japan, and the European Union, central banks started buying government and/or corporate bonds in order to affect the longer-term interest rates directly. Other measures include quantitative easing $(\mathrm{QE})$ and negative short-term wholesale interest rates. The Chinese central bank has more control over long-term interest rates. It has not adopted QE or negative rates. In China, the one-year deposit rate is the benchmark (policy) rate.

Our evidence shows that interest rate liberalization has had a positive effect on monetary policy transmission in China. We find that the mark-up is lower and interest rate pass-through has become more complete in the post-liberalization period. The evidence indicates that monetary policy transmission became more effective after interest rate liberalization, which is most likely due to reform measures introduced by the government as well as more intense competition in the banking industry with the entry of foreign banks, other newly founded domestic banks and non-bank financial institutions.

Furthermore, this study adds new evidence to the debate over the impact of interest rate liberalization on the effectiveness of monetary policy rate transmission. Our sample period covers the time span before the start of the liberalization process. The results indicate that the removal of interest rate control helps improve monetary policy transmission. In addition, this study also contributes to the literature on interest rate rigidity. Prior literature has identified numerous factors that influence rigidity in the interest rate adjustment process, including imperfect competition, information asymmetry, switching cost, and fixed menu cost (Chong 2010). Our study shows that interest rate deregulation is also an important factor for interest rate rigidity. Finally, our study has significant policy implications and is also of interest to the outside world. As China is the second largest economy in the world, effective monetary policy is not just important to the Chinese economy, but also to the world economy.

The remainder of this paper proceeds as follows. Section 2 introduces the background and the process of China's interest rate liberalization. Section 3 reviews the related literature. Section 4 describes the methodology and section 5 presents the empirical results. Section 6 discusses China's banking sector development and its effect on monetary policy transmission. Conclusions are made in section 7. 


\section{Institutional background}

\section{Liberalization of deposit and lending rates}

The Chinese government adopted a very cautious and gradual approach towards interest rate liberalization. Liberalization of the lending rates first started in 1998. The goal was to give commercial banks more authority in pricing their deposits and loans. The gap between the interest rate ceiling and floor was gradually widened over time before being finally removed. Initially, banks could set lending rates between $90 \%$ and $110 \%$ of the benchmark rate for large enterprises, and between $90 \%$ and $130 \%$ of the benchmark rate for small- or medium-sized enterprises. Five years later, the retail lending rate ceiling was removed, but the lending rate floor was maintained for about eight more years. In 2012, the lending rate floor was further lowered to $70 \%$ of the benchmark rate and 1 year later, the lending rate floor was totally removed, suggesting that the PBOC fully liberalized the retail lending rate. Figure 1 shows the timeline of the liberalization process of bank lending rates.

Liberalization of the deposit rates took even longer. The government was more cautious on deposit rate deregulation in order to suppress irrational competition among banks as China did not have a deposit insurance scheme until 2015. The PBOC removed the deposit rate floor in 2004, but banks could not offer higher deposit rates to gain more market share until 2012. The benchmark rate set by the PBOC served as the deposit rate ceiling for about 8 years. Since June 2012, banks could offer deposit rates as high as $110 \%$ of the benchmark rate to their customers. Two years later, the deposit rate ceiling was raised to $120 \%$ of the benchmark rate. In 2015, the PBOC quickened the pace of deposit rate liberalization. The deposit rate ceiling was raised to $130 \%$ of the benchmark rate in March and further to 150\% in May. On October 23, the PBOC removed the ceiling of the deposit rate, signifying that China has completed liberalization of both the retail deposit and lending rates. At the same time, China introduced a deposit insurance scheme which covers RMB 500,000 for each account, thus paving the way for more competition among banks in China.

The interest rate liberalization process in Chinese mainland is similar to the deregulation procedure of interest rules in Chinese Hong Kong; both adopted a gradual and cautious approach to maintain the stability of the financial systems (Chong 2010). However, there are several major differences. First, the reason for the deregulation of interest rules was to encourage bank competition in Chinese Hong Kong, but interest

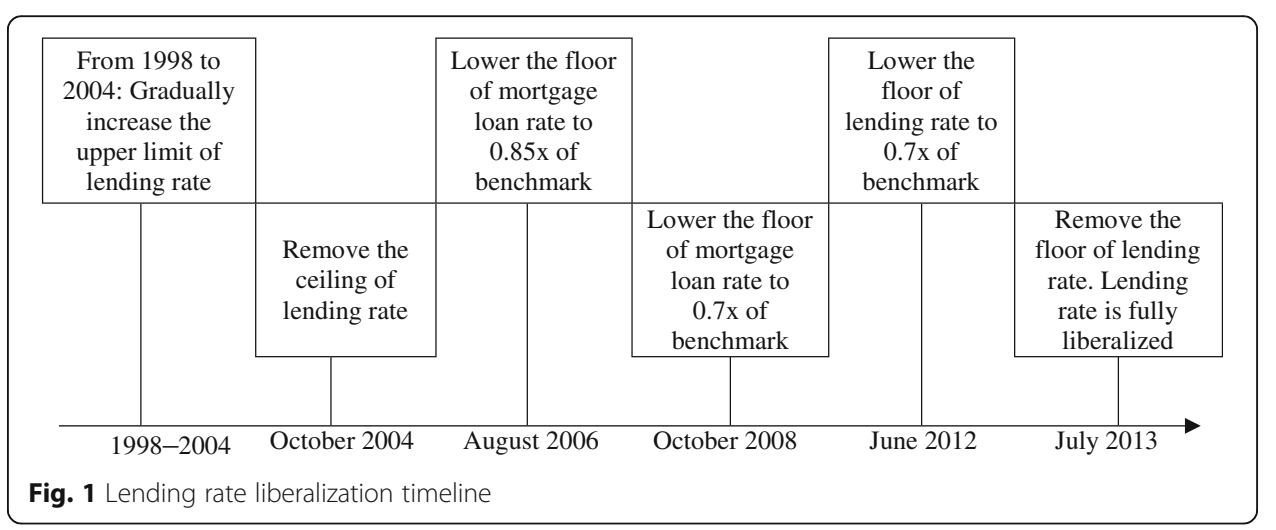


rate liberalization in Chinese mainland was to transfer the pricing power of bank products from the central bank to retail banks. Second, the Hong Kong Monetary Authority only needed to remove the ceiling on the deposit rate, but the PBOC needed to liberalize not only the deposit and lending rates but also inter-bank lending and bond repo rates, the policy bond rate, and the government bond rate, which is far more complicated. ${ }^{2}$ Third, the Hong Kong Monetary Authority gradually removed the ceiling of different deposit products over a span of 7 years, but the PBOC set the ceiling for the retail deposit rates in the first step, then gradually relaxed the limit during the second step and finally removed the limit to fully liberalize the retail deposit rate, which took more than 15 years.

After the interest rate liberalization, the pricing power of banking products has been transferred from the central bank to commercial banks, which can have significant effects on monetary policy transmission. For example, when the PBOC lowers the policy rate to ease monetary policy, commercial banks are likely to lower their retail lending rates to a lesser extent, or defer the downward adjustment of lending rates, which leads to incomplete interest rate pass-through. When the PBOC raises the policy rate under tightening monetary policy, commercial banks may raise their lending rate quickly and more completely, which leads to asymmetric interest rate pass-through. If that is the case, then loosening monetary policy may takes longer to impact the economy than tightening monetary policy.

\section{Monetary policy in China}

The PBOC was legally empowered to operate as the central bank of China in March 1995. Additionally, to promote economic growth and control inflation rates, the PBOC is also required to maintain currency stability. The PBOC has used different tools to control the monetary base and adjust money supply in different time periods. Before 1994, the big four state-owned banks operated as policy banks rather than commercial banks. The PBOC lent directly to the four banks to increase the monetary base according to national bank credit plans. In 1994, three policy banks [the China Development Bank (CDB), the Agricultural Development Bank of China (ADBC), and the Export-Import Bank of China (China Eximbank)] were established to undertake the policy functions of the four banks. The four state-owned banks were gradually privatized, and more and more commercial banks, finance companies, and credit unions emerged. During this period, the PBOC abandoned the national bank credit plans and adjusted money supply indirectly by using monetary tools such as the reserve requirement ratio, discount rate and guidance on credit orientation. After 2008, foreign exchange reserves accumulated rapidly, and the government was forced to inject more local currency to absorb the inflows of foreign currencies. The PBOC increasingly used the reserve requirement ratio to adjust the money supply and maintain the stability of local currency.

Since China's great stimulus program in 2008-2009, "off-balance-sheet" lending and wealth management products of commercial banks developed rapidly, which hampered the effectiveness of traditional monetary policy tools. Soaring real estate prices accompanied a wave of corporate bankruptcies as the funds flowed into high-return areas such as real estate development and local government projects through the channel of 
"off-balance-sheet" lending. The manufacturing firms found it more difficult to obtain funds as a result.

To adjust money supply in targeted areas more accurately, the PBOC introduced a series of new monetary policies such as the Pledged Supplementary Lending (PSL), Temporary Lending Facility (TLF), Standing Lending Facility (SLF), Medium-term Lending Facility (MLF), and Short-term Liquidity Operations (SLO). The MLF was created in September 2014 to provide selected banks with funds to maintain liquidity by allowing them to use securities as collateral. The PBOC can use the MLF to provide lending to targeted areas of the economy rather than injecting liquidity into the whole financial system. For example, to adjust the money supply in April 2017, the PBOC provided RMB128 billion in six-month loans (at an interest rate of 3.05\%) and RMB367.5 billion in one-year loans (at an interest rate of 3.2\%) to banks through an MLF to keep liquidity basically stable. In addition to the MLF, the SLF was introduced in early 2013 and its maximum maturity is usually kept below 1 month. The SLF is comparable to the Federal Reserve's discount window or the European Central Bank's Marginal Lending Facility. The PBOC granted a total of RMB10.89 billion to financial institutions through an SLF. The PBOC also provided RMB83.9 billion to the CDB, the ADBC, and the China Eximbank through a PSL. The PSL was initiated in mid-2014 and aimed to provide low-cost funds to specific sectors, backed by high quality collateral assets. It also helps guide medium-term interest rates.

After January 1998, the government abolished the practice of using the national bank credit plans but increasingly used interest rates administration to adjust the monetary policy stance. The PBOC controlled both the deposit and lending rates with different maturities, of which the one-year deposit rate was the most important. The PBOC determined the one-year deposit rate first, and then used it as the basis to set other deposit rates with different maturities, and finally used the deposit rates to set the corresponding lending rates. The government frequently used interest rates as the primary monetary policy tool to boost or slow its economic growth. For example, the government implemented an expansionary monetary policy by gradually bringing down the policy rates to stimulate economic growth after the 1997 Asian Financial Crisis, but shifted to a tightening monetary policy by gradually raising the policy rates to curb inflation from 2004 to 2007. From 1998 to 2015, the government adjusted the one-year deposit rate 30 times to achieve its policy target.

The PBOC increasingly used open market operations to achieve different policy objectives, such as maintaining the liquidity of the financial market or adjusting the market interest rate. For example, the PBOC used repos and reverse repos to withdraw liquidity from or inject liquidity into the market. The other tools frequently used by the PBOC included central bank bills and notes and treasury deposits (Qiao and Liu 2017). However, open market operations did not influence the one-year deposit rate as it was administrated by the PBOC. As the one-year deposit rate is usually used as the reference rate to price the floating-rate government and corporate securities, it will influence the market interest rate, which leads to a reverse transmission of monetary policy from the retail deposit rate to the wholesale market interest rate (Liu and Margaritis 2014).

In 2007, the PBOC launched the Shanghai Interbank Offered Rate (SHIBOR). Although the SHIBOR is a market-oriented wholesale interest rate and has a growing 
impact on the pricing of an increasing number of financial products, its influence on the retail deposit and lending rates is still limited. After the completion of interest rate liberalization on October 23, 2015, the PBOC still sets benchmark policy deposit and lending rates, which are still the primary determinants of retail deposit and lending rates.

\section{Literature review}

\section{Interest rate pass-through}

The degree of interest rate pass-through from the policy rate to the interest rates of commercial banks is very important in measuring the effectiveness of monetary policy transmission and the question has been widely explored in the literature. Many studies in the literature assume the pass-through of policy rates to banks' retail deposit and loan rates is immediate and complete (Bernanke and Gertler 1995; Gertler and Gilchrist 1994). While this assumption is reasonable for developed countries like the US, it may not be the case for other countries due to various factors, such as an uncompetitive banking industry, untrustworthy central banks, and/or ineffective conduct and communication of monetary policies. Indeed, a growing body of literature in recent years show that the interest rate pass-through may be sluggish, incomplete, and asymmetric (Chong 2010; Kopecky and van Hoose 2012). Kleimeier and Sander (2006) study the pass-through process of expected and unexpected monetary policy impulses and find that the expected monetary policy impulses are passed to retail interest rates more quickly, suggesting that good communication by the central bank can improve the effectiveness of monetary policy transmission. Liu et al. (2008) examine how the transparency of monetary policy influences its transmission. They find that transparency improves monetary policy transmission by reducing the volatility of official policy rates.

Further, in uncompetitive markets, rates may be fast to go up but slow to come down, i.e., the rocket and feathers phenomenon. The findings have important policy implications as the effectiveness of monetary policy is determined by how fast changes in the policy rate are passed to retail deposit and loan rates. If the transmission is slow, monetary policy takes time to impact the economy. Further, if the pass-through is asymmetric, cuts in policy rates or a loose monetary policy take longer to work than increases in policy rates or a tight monetary policy.

Hristov et al. (2014) study whether the 2008 Global Financial Crisis distorted the effectiveness of monetary policy transmission in the Euro zone. They find that the interest rate pass-through was generally complete before the crisis, but it became less efficient thereafter. The deterioration of monetary policy transmission is due to the structural changes after the crisis, such as the lower values of loans, less competition among banks, and weaker bank capital. Ciccarone et al. (2014) contend that a less efficient monetary policy transmission can be caused by frictions in the labor and credit markets. Kwapil and Scharler (2010) show that the incompleteness of the long-run interest rate pass-through hampers macroeconomic stability. For a comprehensive review of interest rate pass-through in the Euro zone, see Andries and Billon (2016).

\section{Monetary policy transmission in China}

The evidence on the effectiveness of monetary policy transmission in China is mixed. Fernald et al. (2014) indicate that the transmission of increases in interest rates and 
reserve requirements has become more effective with China's financial liberalization. However, Chen et al. (2017) show that monetary policy transmission is not effective through the bank lending channel. Yang and Shao (2016) suggest that higher bank competition weakens the transmission of monetary policy through the bank lending channel. Wong and Poon (2011) find that monetary policy transmission was effective through the bank lending channel before the 2008 Global Financial Crisis, but was affected by changes to the asset-price channels afterward.

A number of factors that influence the effectiveness of monetary policy transmission have also been identified in the literature. He et al. (2013) show that the exchange rate should be taken into account when considering the effectiveness of monetary policy transmission. Wang et al. (2017) show that borrowing constraints on private firms impede the effectiveness of monetary policy transmission. Fungáčová et al. (2016) find that banks' ownership structures influence monetary policy transmission through the bank lending channel. Hou and Wang (2013) suggest that the transmission of monetary policy tightening by adjusting reserve requirements is less effective as the degree of bank marketization improves.

In the context of interest rate pass-through in China, He and Wang (2012) provide both theoretical and empirical demonstrations to show that market interest rates are more sensitive to changes in the policy rate, and less reactive to open market operations. Jin et al. (2014) examine the pass-through of bank retail rates to interbank rates and find that both the short-term pass-through and the adjustment speed are asymmetric. However, the above two studies do not examine the relationship between the policy rates and bank lending rates and do not consider the impact of interest rate liberalization on the effectiveness of the transmission of the monetary policy rate.

Liu et al. (2018) examine the issue from 2007 to 2017 and find that the interest rate pass-through is less complete after interest rate liberalization. As interest rate liberalization started in 1999 and the lending rate ceiling as well as the deposit rate floor was removed in 2004, their results fail to provide a full picture of the impact of interest rate liberalization as the interest rate pass-through before the start of the liberalization process has been overlooked.

\section{Methodology}

\section{ARDL bound test}

Before estimating the long-term relationship between the policy rate and bank lending rates, we need to test whether they are cointegrated. We use the ARDL bound test (Pesaran et al. 2001) to examine whether there is a long-run equilibrium relationship between the policy rate and the retail lending rates. The empirical model is as follows:

$$
\begin{aligned}
\Delta y_{t}= & \beta_{0}+\beta_{1} \Delta y_{t-1}+\beta_{2} \Delta y_{t-2}+\ldots+\beta_{p} \Delta y_{t-p}+\alpha_{0} \Delta x_{t}+\alpha_{1} \Delta x_{t-1}+\ldots \\
& +\alpha_{q} \Delta x_{t-q}+\theta_{0} y_{t-1}+\theta_{1} x_{t-1}+\varepsilon_{t} .
\end{aligned}
$$

The dependent variable $\Delta y_{t}$ represents the change in bank lending rates in period $t$. For the independent variables, $\Delta y_{t-p}$ represents the change in lending rates with $p$ periods' lag. $\Delta x_{t}$ means the change in policy rates at period $t$ while $\Delta x_{t-q}$ means the change in policy rates with $q$ periods' lag. The term $y_{t-1}$ means the bank lending rates at period $t-1$, while $x_{t-1}$ means the policy rates at the same period. $\varepsilon_{t}$ is the residual term. 
The ARDL model has some apparent advantages in comparison with the traditional error correction model (ECM). The ECM assumes the series should have the same order of integration, but the ARDL model works when some of the series are stationary and some of them are I (1). ${ }^{3}$ Further, the ARDL is more efficient when using a small sample in the empirical analysis.

The null hypothesis is that $\theta_{0}=\theta_{1}=0$, i.e., there is no long-term relationship. Rejection of the null hypothesis means we can accept the alternative hypothesis that there is a long-run equilibrium between the two variables. If the null hypothesis is rejected, we regress $y_{t-1}$ on $x_{t-1}$ and define the residual term $z_{t-1}$ as follows:

$$
y_{t-1}=\gamma_{0}+\gamma_{1} x_{t-1}+z_{t-1} .
$$

We use the residual term $z_{t-1}$ to replace $\theta_{0} y_{t-1}+\theta_{1} x_{t-1}$ in the eq. (1) and remove the constant term to get the ECM model as follows:

$$
\begin{aligned}
\Delta y_{t}= & \beta_{1} \Delta y_{t-1}+\beta_{2} \Delta y_{t-2}+\ldots+\beta_{p} \Delta y_{t-p}+\alpha_{0} \Delta x_{t}+\alpha_{1} \Delta x_{t-1}+\ldots+\alpha_{q} \Delta x_{t-q} \\
& +\pi z_{t-1}+\varepsilon_{t} .
\end{aligned}
$$

We use the AIC criterion to determine the maximum of lags $p$ and $q$ in Model (3). We then use the serial correlations for the errors of this model to determine the lag values of $p$ and $q$. Finally, we check the stability of the model by looking at the inverse roots of the associated characteristic equation to ensure that all roots are inside the unit circle.

We perform the ARDL bound test to examine whether the coefficients $\theta_{0}$ and $\theta_{1}$ in eq. (1) are both statistically significantly different from zero. First, we impose the restriction $\theta_{0}=\theta_{1}=0$ in eq. (1) and use the Wald test for the restricted equation to find both the $F$-statistics and the degree of freedom. Then we use the $F$-statistics to determine the significance level for the long-run relationship between the policy deposit rate and the retail lending rates.

\section{The impact of interest rate liberalization on the long-term relationship}

To examine whether interest rate liberalization influences the degree of the long-term pass-through from the one-year policy rate to the lending rates of commercial banks in China, we define the dummy variable $D=1$ for the time after July 2013, when the lending rate ceiling and floor was completely removed, and the lending rate was fully liberalized. We add the dummy variable in the long-run equilibrium regression model and modify Model (2) as follows:

$$
y_{t}=\gamma_{0}+\lambda_{0} \mathrm{D}+\gamma_{1} x_{t}+\lambda_{1} D \times x_{t}+z_{t} .
$$

The coefficient $\lambda_{0}$ captures the difference in the mark-ups before and after interest rate liberalization. The coefficient $\lambda_{1}$ captures the change in the long-run interest rate pass-through before and after interest rates were liberalized.

\section{The impact of interest rate liberalization on the short-term relationship}

We also add the dummy variable to the ECM Model (3) and modify it as follows: 


$$
\begin{aligned}
\Delta y_{t}= & \beta_{1} \Delta y_{t-1}+\beta_{2} \Delta y_{t-2}+\ldots+\beta_{p} \Delta y_{t-p}+\alpha_{0} \Delta x_{t}+\alpha_{1} \Delta x_{t-1}+\ldots+\alpha_{q} \Delta x_{t-q} \\
& +\omega_{0} D \times \Delta x_{t}+\omega_{1} D \times \Delta x_{t-1}+\ldots+\omega_{q} D \times \Delta x_{t-q}+\pi z_{t-1}+\varepsilon_{t} .
\end{aligned}
$$

The coefficients from $\omega_{0}$ to $\omega_{q}$ capture the difference in the short-run interest rate pass-through before and after interest rate liberalization. We use a general-to-specific approach to select the number of lags.

\section{The impact of interest rate liberalization on the asymmetric adjustment}

Finally, we distinguish between positive and negative residual terms. We define $z_{t-1}^{+}$as $z_{t-1}$ when $z_{t-1}$ is positive, and zero otherwise. It measures the downward adjustment speed when the lending rate is above its equilibrium. We define $z_{t-1}^{-}$as $z_{t-1}$ when $z_{t-1}$ is negative, and zero otherwise. It measures the upward adjustment speed when the lending rate is below its equilibrium. We modify Model (5) as follows:

$$
\begin{aligned}
\Delta \mathrm{y}_{t}= & \beta_{1} \Delta y_{t-1}+\beta_{2} \Delta y_{t-2}+\ldots+\beta_{p} \Delta y_{t-p}+\alpha_{0} \Delta x_{t}+\alpha_{1} \Delta x_{t-1}+\ldots+\alpha_{q} \Delta x_{t-q} \\
& +\omega_{0} D \times \Delta x_{t}+\omega_{1} D \times \Delta x_{t-1}+\ldots+\omega_{q} D \times \Delta x_{t-q}+\pi_{1} z_{t-1}^{+}+\pi_{2} z_{t-1}^{-} \\
& +\pi_{3} D \times z_{t-1}^{+}+\pi_{4} D \times z_{t-1}^{-}+\varepsilon_{t} .
\end{aligned}
$$

In Model (6), $\pi_{1}$ measures the downward adjustment speed when the lending rate is above its equilibrium before liberalization, while $\pi_{1}+\pi_{3}$ measures the downward adjustment speed after liberalization. $\pi_{2}$ measures the upward adjustment speed when the lending rate is below its equilibrium before liberalization, while $\pi_{2}+\pi_{4}$ measures the upward adjustment speed after liberalization. We use the Wald test to examine the null hypothesis of $\pi_{1}=\pi_{2}$. Rejection of the null hypothesis implies that there is an asymmetric interest rate pass-through before liberalization. We also examine the null hypothesis of $\pi_{1}+\pi_{3}=\pi_{2}+\pi_{4}$. Rejecting the hypothesis implies that there is an asymmetric interest rate pass-through after liberalization. We use a general-to-specific approach to select the number of lags.

\section{Data and empirical results}

\section{Data}

We collect the monthly time series of one-year policy rate from the website of the PBOC. We collect the short-term (i.e., one-year and below) lending rates from the website of the ICBC. ${ }^{4}$ The sample period is from January 1995 to December 2017. The number of observations is 276 . Figure 2 shows the two-time series over the sampling period.

Panel A of Table 1 reports the summary statistics for the two-time series. We find that the range for both variables is large during the sample period. For example, the minimum policy rate is $1.50 \%$ while its maximum achieves $10.98 \%$. We also notice that their means are greater than the median. The median is close to the minimum but far from the maximum. The strong right-skewness of both the policy rate and the lending rate indicates that the frequency of low interest rates is high, implying the prevalence of expansionary monetary policy during our sample period. The mean of the first differences of the time series of both the policy rate and the lending rate are negative. The largest downward adjustment of the policy rate is 180 basis points, while its largest upward adjustment is only 27 points. The asymmetry indicates that the government is more cautious in implementing a tightening monetary policy. 


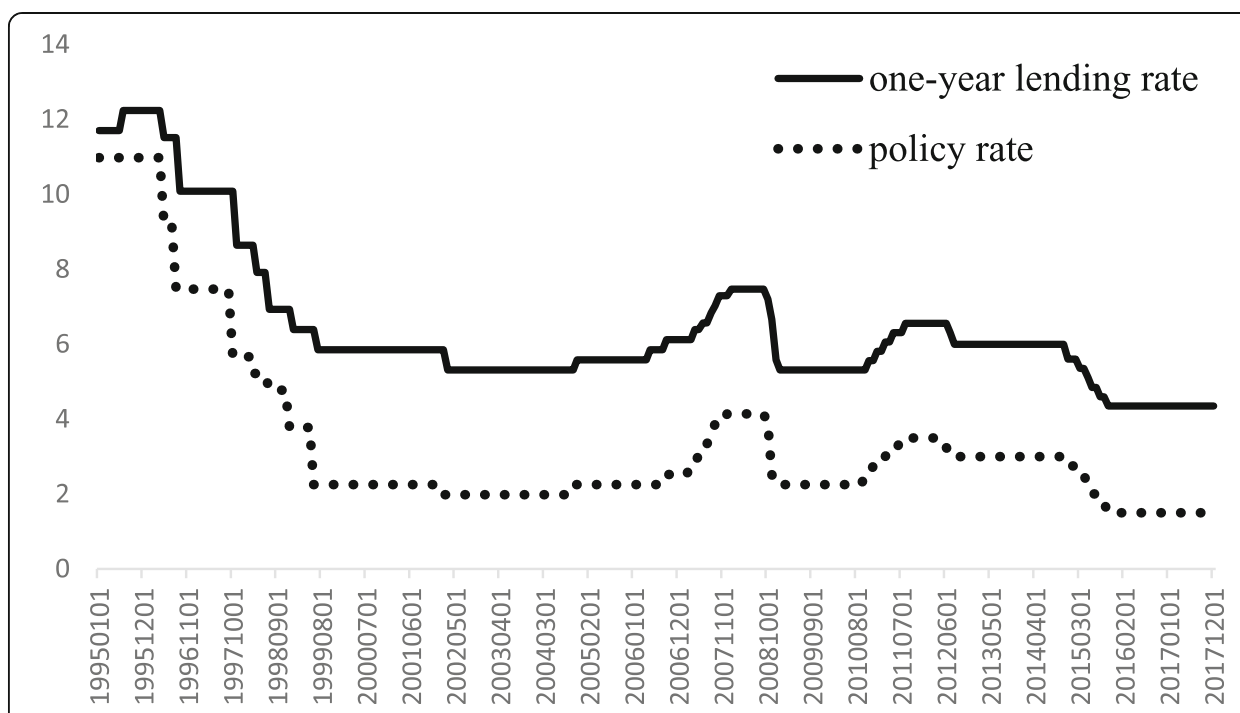

Fig. 2 Time series of one-year lending rate and policy rate from 1995 to 2017

Panel B reports the correlation matrix for the policy rate and the lending rate. The result shows that their association is positive and strong at $98 \%$. Panel $\mathrm{C}$ reports the correlation matrix for their first difference. The coefficient is $24 \%$.

\section{ARDL test}

Table 2 reports the results for the ARDL Model (1). In the regression model, the time lags $p$ and $q$ are both equal to 3. Panel B reports the result of the Bound test. The $F$-statistics is 4.21 and is statistically significant at $10 \%$. The result indicates that the policy rate and the retail lending rate are cointegrated and, therefore, have a long-term relationship.

Table 1 Summary statistics and correlation matrix

\begin{tabular}{|c|c|c|c|c|c|c|}
\hline \multicolumn{7}{|c|}{ Panel A: Summary statistics } \\
\hline & Average & Median & S.D. & Min & Max & Obs. \\
\hline \multicolumn{7}{|l|}{ Level } \\
\hline Policy rate & 3.45 & 2.25 & 2.41 & 1.50 & 10.98 & 276 \\
\hline Lending rate & 6.47 & 5.85 & 1.98 & 4.35 & 12.24 & 276 \\
\hline \multicolumn{7}{|l|}{ First-difference } \\
\hline$\Delta$ Policy rate & -0.03 & 0 & 0.24 & -1.80 & 0.27 & 275 \\
\hline$\Delta$ Lending rate & -0.03 & 0 & 0.19 & -1.44 & 0.54 & 275 \\
\hline \multicolumn{7}{|c|}{ Panel B: Correlation matrix for the level of the interest rate series } \\
\hline & Policy rate & Lending & & & & \\
\hline Policy rate & 1.00 & 0.98 & & & & \\
\hline Lending rate & 0.98 & 1.00 & & & & \\
\hline \multicolumn{7}{|c|}{ Panel C: Correlation matrix for first-difference of the interest rate series } \\
\hline & Policy rate & Lending & & & & \\
\hline$\Delta$ Policy rate & 1.00 & 0.24 & & & & \\
\hline$\Delta$ Lending rate & 0.24 & 1.00 & & & & \\
\hline
\end{tabular}


Table 2 The ARDL bound test

\begin{tabular}{|c|c|c|c|c|c|}
\hline \multicolumn{6}{|c|}{ Panel A: The ARDL results } \\
\hline \multicolumn{6}{|c|}{$\Delta y_{t}=\beta_{0}+\beta_{1} \Delta y_{t-1}+\beta_{2} \Delta y_{t-2}+\ldots+\beta_{p} \Delta y_{t-p}+a_{0} \Delta x_{t}+a_{1} \Delta x_{t-1}+\ldots+a_{q} \Delta x_{t-q}+\theta_{0} y_{t-1}+\theta_{1} x_{t-1}+\varepsilon_{t}$} \\
\hline Variable & & Coefficient & S.E. & t-statistics & Prob. \\
\hline Constant & $\beta_{0}$ & 0.243 & 0.0824 & 2.95 & 0.004 \\
\hline$y_{t-1}$ & $\theta_{0}$ & -0.0707 & 0.0221 & -3.19 & 0.001 \\
\hline$x_{t-1}$ & $\theta_{1}$ & 0.0623 & 0.0182 & 3.42 & 0.000 \\
\hline$\Delta y_{t-1}$ & $\beta_{1}$ & -0.193 & 0.0612 & -3.16 & 0.002 \\
\hline$\Delta y_{t-2}$ & $\beta_{2}$ & 0.107 & 0.0620 & 1.72 & 0.086 \\
\hline$\Delta y_{t-3}$ & $\beta_{2}$ & 0.0824 & 0.0393 & 2.10 & 0.037 \\
\hline$\Delta x_{t}$ & $a_{0}$ & 0.192 & 0.0318 & 6.04 & 0.000 \\
\hline$\Delta x_{t-1}$ & $a_{1}$ & 0.565 & 0.0355 & 15.90 & 0.000 \\
\hline$\Delta x_{t-2}$ & $a_{2}$ & 0.116 & 0.0497 & 2.33 & 0.021 \\
\hline$\Delta x_{t-3}$ & $a_{3}$ & -0.0975 & 0.0492 & -1.98 & 0.048 \\
\hline \multicolumn{6}{|c|}{ Panel B: Bound test (Null hypothesis: No long-term relationship) } \\
\hline B & Value & Significance & $\mathrm{I}(0)$ & $\mathrm{I}(1)$ & \\
\hline F-statistics & 4.21 & $10 \%$ & 3.02 & 3.51 & \\
\hline \multirow[t]{3}{*}{ k } & 1 & $5 \%$ & 3.62 & 4.16 & \\
\hline & & $2.5 \%$ & 4.18 & 4.79 & \\
\hline & & $1 \%$ & 4.94 & 5.58 & \\
\hline
\end{tabular}

\section{The long-term relationship}

Table 3 reports the results of Model (4), i.e., the long-term relationship between the one-year policy rate and bank lending rates. The constant, $\gamma_{0}$, is 3.955 , suggesting that the average mark-up is $3.95 \%$ before the completion of lending rate liberalization. The coefficient of the dummy variable, $\lambda_{0}$, is -1.175 , implying that the average mark-up decreases 278 basis points after liberalization. The evidence indicates that interest rate liberalization has negative effects on the markup or the spread between lending rates and deposit rates and, hence, bank profitability. It implies that the competition in the banking industry has increased significantly in the second sub-period.

The slope coefficient $\gamma_{1}$ captures the long-run pass-through from the policy rate to the retail lending rate before the completion of lending rate liberalization. The long-run pass-through is about $70 \%$ during this period. The coefficient of the interactive variable between the policy rate and the dummy variable, $\lambda_{1}$, is positive and statistically significant, suggesting that the long-run pass-through improved after liberalization. The evidence shows that the long-run pass-through is complete $(0.76+$ $0.36=1.12$ ) after interest rate liberalization.

Table 3 Long-run relationship between the policy rate and the bank lending rate

\begin{tabular}{|c|c|c|c|c|c|}
\hline \multicolumn{6}{|c|}{$y_{t}=\gamma_{0}+\lambda_{0} D+\gamma_{1} x_{t}+\lambda_{1} D \times x_{t}+z_{t}$} \\
\hline Variable & & Coefficient & S. E. & $t$-statistics & Prob. \\
\hline Constant & $\gamma_{0}$ & 3.955 & 0.0959 & 41.236 & 0.000 \\
\hline$D$ & $\lambda_{0}$ & -1.175 & 0.196 & 5.983 & 0.000 \\
\hline$x_{t-1}$ & $\gamma_{1}$ & 0.761 & 0.0172 & 44.177 & 0.000 \\
\hline$D \times x_{t-1}$ & $\lambda_{1}$ & 0.362 & 0.0657 & 5.514 & 0.000 \\
\hline
\end{tabular}


The above results on the long-run analysis indicate that interest rate liberalization has positive effects on improving interest rate pass-through. Liberalization also has negative effects on net interest margins and, therefore, bank profitability. The evidence shows that monetary policy transmission become more effective after liberalization.

\section{Short-term dynamics}

Next, we conduct analysis to study the short-run relationship between the policy rate and the retail lending rate. Table 4 reports the results of Model (5), i.e., the short-run dynamics. Prior to interest rate liberalization, the short-run pass-through from the policy rate to the lending rate is captured by the sum of $\alpha_{0}, \alpha_{1}$ and $\alpha_{2}$. The result indicates that about $74 \%$ of the change in the policy rate is passed to the lending rate within 3 months. The evidence indicates that the short-run pass-through is fast. After liberalization, the short-run pass-through is captured by the sum of $\alpha_{0}, \alpha_{1}, \alpha_{2}$ and $\omega_{0}$, $\omega_{1}, \omega_{2}$. The coefficients of $\omega_{0}, \omega_{1}, \omega_{2}$ are positive and statistically significant, suggesting that the short-run pass-through improved after liberalization. The sum of $\alpha_{0}, \alpha_{1}, \omega_{0}$ and $\omega_{1}$ is greater than one, suggesting that the change in the policy rate is completely passed to the lending rate within two months.

The above evidence indicates that the short-run pass-through is faster and more complete after interest rate liberalization. The evidence is consistent with the long-run analysis and supports the view that interest rate liberalization has positive effects on the effectiveness of monetary policy transmission.

\section{Asymmetric adjustment speed}

We further distinguish between the downward and upward adjustment speed of interest rates (i.e., the error correction) and use $z_{t-1}^{+}$and $z_{t-1}^{-}$to replace the error term $z_{t-1}$ in Model (5). We denote the coefficient of $z_{t-1}^{+}$as $\pi_{1}$ and the coefficient of $z_{t-1}^{-}$as $\pi_{2}$ and report the results in Table 5. Over the entire sample period, the downward adjustment speed is $11.7 \%$, while the upward adjustment speed is $6.2 \%$. However, the difference is not statistically significant. We, therefore, do not find the asymmetric adjustment speeds for the entire sample period.

We conduct additional tests to examine whether interest rate liberalization influences the upward and downward adjustment speed. Table 6 reports the results of Model (6).

Table 4 The short-run relationship: Symmetric model

\begin{tabular}{|c|c|c|c|c|c|}
\hline \multicolumn{6}{|c|}{$\Delta y_{t}=\beta_{1} \Delta y_{t-1}+\beta_{2} \Delta y_{t-2}+a_{0} \Delta x_{t}+a_{1} \Delta x_{t-1}+a_{2} \Delta x_{t-2}+\omega_{0} D \times \Delta x_{t}+\omega_{1} D \times \Delta x_{t-1}+\omega_{2} D \times \Delta x_{t-2}+\pi z_{t-1}+\varepsilon_{t}$} \\
\hline Variable & & Coefficient & S. E. & t-statistics & Prob. \\
\hline$\Delta y_{t-1}$ & $\beta_{1}$ & -0.256 & 0.0597 & -4.29 & 0.000 \\
\hline$\Delta y_{t-2}$ & $\beta_{2}$ & -0.0207 & 0.0386 & -0.54 & 0.592 \\
\hline$\Delta x_{t}$ & $a_{0}$ & 0.128 & 0.0319 & 4.00 & 0.000 \\
\hline$\Delta x_{t-1}$ & $a_{1}$ & 0.491 & 0.0384 & 12.80 & 0.000 \\
\hline$\Delta x_{t-2}$ & $a_{2}$ & 0.122 & 0.0463 & 2.64 & 0.009 \\
\hline$D \times \Delta x_{t}$ & $\omega_{0}$ & 0.157 & 0.0745 & 2.11 & 0.036 \\
\hline$D \times \Delta x_{t-1}$ & $\omega_{1}$ & 0.261 & 0.0761 & 3.43 & 0.001 \\
\hline$D \times \Delta x_{t-2}$ & $\omega_{2}$ & 0.130 & 0.0765 & 1.70 & 0.090 \\
\hline$z_{t-1}$ & $\pi$ & -0.0949 & 0.0272 & -3.49 & 0.001 \\
\hline
\end{tabular}


Table 5 The short-run relationship: Asymmetric adjustment

\begin{tabular}{|c|c|c|c|c|c|}
\hline \multicolumn{6}{|c|}{$\begin{array}{l}\text { Panel A: } \Delta y_{t}=\beta_{1} \Delta y_{t-1}+\beta_{2} \Delta y_{t-2}+a_{0} \Delta x_{t}+a_{1} \Delta x_{t-1}+a_{2} \Delta x_{t-2}+\omega_{0} D \times \Delta x_{t}+\omega_{1} D \times \Delta x_{t-1}+\omega_{2} D \times \Delta x_{t-2}+\pi_{1} z_{t-1}^{+}+\pi_{2} z_{t-1}^{-} \\
+\varepsilon_{t}\end{array}$} \\
\hline Variable & & Coefficient & S. E. & t-statistics & Prob. \\
\hline$\Delta y_{t-1}$ & $\beta_{1}$ & -0.257 & 0.0598 & -4.29 & 0.000 \\
\hline$\Delta y_{t-2}$ & $\beta_{2}$ & -0.0260 & 0.0390 & -0.67 & 0.505 \\
\hline$\Delta x_{t}$ & $a_{0}$ & 0.121 & 0.0327 & 3.69 & 0.000 \\
\hline$\Delta x_{t-1}$ & $a_{1}$ & 0.475 & 0.0420 & 11.33 & 0.000 \\
\hline$\Delta x_{t-2}$ & $a_{2}$ & 0.116 & 0.0467 & 2.49 & 0.013 \\
\hline$D \times \Delta x_{t}$ & $\omega_{0}$ & 0.165 & 0.0750 & 2.20 & 0.029 \\
\hline$D \times \Delta x_{t-1}$ & $\omega_{1}$ & 0.271 & 0.0769 & 3.52 & 0.001 \\
\hline$D \times \Delta x_{t-2}$ & $\omega_{2}$ & 0.137 & 0.0769 & 1.79 & 0.075 \\
\hline$z_{t-1}^{+}$ & $\pi_{1}$ & -0.117 & 0.0359 & -3.27 & 0.001 \\
\hline$z_{t-1}^{-}$ & $\pi_{2}$ & -0.0625 & 0.0435 & -1.44 & 0.152 \\
\hline \multicolumn{6}{|c|}{ Panel B: Wald test (Null hypothesis: $\pi_{1}=\pi_{2}$ ) } \\
\hline Test-Statistics & Value & & $d f$ & & Prob. \\
\hline t-statistics & -0.955 & & 263 & & 0.340 \\
\hline F-statistics & 0.912 & & $(1,263)$ & & 0.340 \\
\hline Chi-square & 0.912 & & 1 & & 0.340 \\
\hline
\end{tabular}

The evidence indicates that prior to interest rate liberalization, the downward adjustment speed is $20.6 \%$, which is faster than the upward adjustment speed of $6.7 \%$. Panel B shows that we can reject the null hypothesis $\pi_{1}=\pi_{2}$ at the $10 \%$ level, suggesting that there is weak evidence that interest rate pass-through was asymmetric before liberalization. After liberalization, the downward adjustment speed decreases to $1 \%$ and the upward adjustment speed decreases to $1.7 \%$, implying that the asymmetric adjustment speeds disappear after interest rate liberalization, as shown in Panel C.

\section{Discussion}

Our findings suggest that China's interest rate liberalization does not negatively affect monetary policy transmission. ${ }^{5}$ In contrast, we find that after liberalization the mark-up is lower, the long-run interest rate pass-through is more complete and the short-run pass-through is faster and more complete.

This phenomenon can be explained by the changes in the structure of China's banking sector. During the interest rate liberalization process, the government adopted a series of policies or regulations which resulted in the emergence of numerous different commercial banks and financial institutions (Wang 2016). The government gradually lowered the entry barrier to the banking sector and encouraged the establishment and development of non-state-owned banks and financial institutions, which led to substantial changes in the structure of China's banking sector. The Commercial Bank Law of the People's Republic of China was enacted in 1995, which paved the way for developing non-state-owned banks in China's financial system.

Before the enactment of the Commercial Bank Law, China's big four state-owned banks operated as government bodies. According to the Provisional Regulations on the Administration of Banks enacted in 1986, the banks and other financial institutions should "implement the financial policy of the state." The objective of their operations is to "stimulate the economic development, maintain the stability of currencies, and enhance the economic effectiveness." Banks should "make loans to enterprises according 


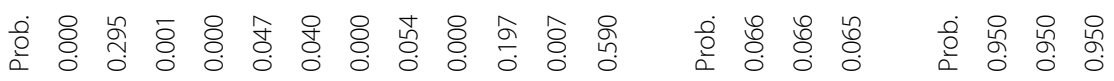

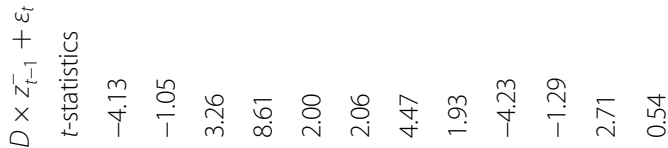

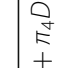

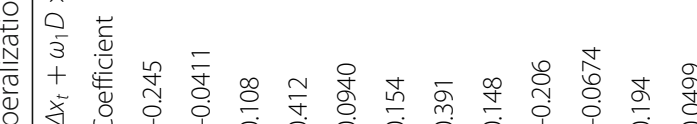


to the policy and the plan of the state." In 1994, the three policy banks were established to gradually take the business related to the government's financial policy implementations from the big four state-owned banks. The state-owned banks were restructured to joint-stock banks and three of them went to IPO between 2005 and 2006, while the $\mathrm{ABC}$ went to IPO in 2010.

Various measures were taken to enhance the development of city joint-stock banks. In 1997, the PBOC issued three important regulations, including the Regulations on the City Cooperative Banks, the Instructions on Setting Up A City Commercial Bank, and the Instructions on Evaluations on New City Commercial Banks, to provide details on how to set up a city commercial bank. The government implemented various kinds of policies to help 12 national joint-stock banks survive the 1997 Asian Financial Crisis, including approval of their capital injection, restructuring, acquisitions, or helping them raise funds from the capital markets. In 2002, the PBOC issued the Guideline on the Governance of Joint-Stock Banks and the Guideline on the Independent Board Members and External Supervisors of Joint-Stock Banks to help these banks improve their corporate governance.

The city commercial banks operated regionally in the beginning, and were allowed to open branches in other cities after the issuance of the Regulations on the Non-Local Branches of City Commercial Banks in 2006. In 2007, a handful of city banks went to IPO and became public companies, suggesting that city banks have gained access to capital markets for raising funds.

At the same time, private capital was encouraged to enter the banking or financial sector in rural areas. In 2007, the China Banking Regulatory Commission (CBRC) issued a series of regulations, including the Interim Provisions on Management of Village Banks, the Interim Provisions on Management of Loan Companies, the Guidelines for the Examination and Approval of the Establishment of Village Banks, and the Guidelines for the examination and approval of the establishment of loan companies, to establish the institutional framework for setting up new village banks and new loan companies. In 2008, the CBRC and the PBOC jointly issued the Guideline on Setting Up Small Loan Companies, which empowered local governments to approve the setting up of small loan companies. In 2009, the CBRC issued the Interim Provisions on the Reform of Small Loan Companies and Establishment of Village Banks, which encouraged reputable loan companies to be restructured to become village banks. In 2010, the government issued the Several Opinions of the State Council on Encouraging and Guiding the Healthy Development of Private Investment, which provided private capital and the legal foundations to enter the financial and banking sector. In 2012, the CBRC issued the Implementation Opinion on Encouraging and Guiding Private Capital into Bank Industry, which further confirmed that state supported private capital was to take an important role in the banking sector.

After 2013, iFinance developed quickly and became more and more important in China's financial sector. In 2013, the government encouraged financial innovation and in 2014, it issued the Opinions on Further Fueling the Smooth Development of the Capital Market, which supported IT companies to engage in Internet finance activities.

Our findings can further be explained by China's ongoing financial reform, which has led to substantial decreases in the concentration level of its banking sector. The Chinese government has successfully transformed its stated-owned banks into public firms, 
which has improved their operating efficiency. The government has also succeeded in enhancing the competitiveness of its banking sector by establishing five layers of commercial banks. The first layer consists of the five big state-owned banks. The second layer consists of 12 national banks, established and operating under the market economy. The third layer consists of hundreds of city commercial banks, which were reorganized from cities' credit unions. The fourth layer consists of small commercial banks and other financial institutions in rural areas, which absorb private capital and help to resolve illegal lending problems. The remaining consists of foreign banks, policy banks and other financial institutions.

\section{Conclusions}

We examine how interest rate liberalization influences the effectiveness of monetary policy transmission. We find that the long-run and the short-run pass-through from the policy rates to retail lending rates became faster and more complete after interest rate liberalization. We attribute the findings to the structural changes of China's banking sector. Our results indicate that China's financial system reform has successfully enhanced the competition level of its banking sector. Our results are different from those of Liu et al. (2018), who show that after interest rate liberalization the pass-through of the policy rates to the bank retail rates is less complete. As their sample period started in 2007 and they did not consider the pass-through behavior before the start of the liberalization process, their results fail to provide a full picture. Our results are consistent with those of Chong (2010), who examines the impact of interest rate deregulation on the effectiveness of monetary policy in Hong Kong and finds that removal of the deposit rate ceiling improved the degree of pass-through from the market interest rate to the retail bank rates. We compare the pass-through behavior from the policy deposit rates to the bank lending rates in China before and after its interest rate liberalization and find interest rate regulation enhances the transmission of monetary policy.

\section{Endnotes}

${ }^{1}$ The four banks are the Industrial and Commercial Bank of China (ICBC), Bank of China (BOC), China Construction Bank (CCB), and Agricultural Bank of China (ABC).

${ }^{2}$ Wholesale interest rate liberalization began in 1993. The inter-bank lending rate was liberalized in 1996, the inter-bank bond repo rate was liberalized in 1997, the policy bond rate was liberalized in 1998 and government bonds were issued through open bidding in 1999. In 2000, the lending rate for foreign currency loans was liberalized.

${ }^{3} \mathrm{We}$ apply the ADF test to the policy deposit rates and bank lending rates as well as their first difference and find neither series is I(2).

${ }^{4}$ The lending rates of all the big four banks in China were collected and they are virtually the same.

${ }^{5} \mathrm{We}$ also examine the pass-through of the policy rate to the intermediate-term lending rates (with a maturity from three to 5 years) and the long-term lending rates (with a maturity over 5 years) and do not find evidence that interest rate liberalization has negative effects on the effectiveness of monetary policy transmission. 


\section{Acknowledgements}

The authors would like to thank the seminar participants of The 2018 FBR International Conference and Dr. Yong Kyu Gam (discussant) for their helpful comments. We would also like to thank two anonymous referees for their constructive comments and suggestions.

\section{Funding}

Not applicable.

\section{Availability of data and materials}

The datasets analyzed during the current study are available on the websites of the People's Bank of China and Industrial and Commercial Bank of China,

http://www.pbc.gov.cn/zhengcehuobisi/125207/125213/125440/125838/125888/index.html

http://www.icbc.com.cn/ICBC/\%E9\%87\%91\%E8\%9E\%8D\%E4\%BF\%A1\%E6\%81\%AF/

\%E5\%AD\%98\%E8\%B4\%B7\%E6\%AC\%BE\%E5\%88\%A9\%E7\%8E\%87\%E8\%A1\%A8/

\%E4\%BA\%BA\%E6\%B0\%91\%E5\%B8\%81\%E8\%B4\%B7\%E6\%AC\%BE\%E5\%88\%A9\%E7\%8E\%87\%E8\%A1\%A8/default.htm

\section{Authors' contributions}

$J \mathrm{~L}$ is the main contributor. This is part of her PhD thesis. She analyzed the data and wrote the initial draft. M-HL provided research guidance, helped in interpreting the empirical results and revising the manuscript. Both authors read and approved the final manuscript.

\section{Authors' information}

Ms. Jingya Li is a PhD candidate of University of Macau. Dr. Ming-Hua Liu is an associate professor of the Faculty of Business Administration, University of Macau.

\section{Competing interests}

The authors declare that they have no competing interests.

\section{Publisher's Note}

Springer Nature remains neutral with regard to jurisdictional claims in published maps and institutional affiliations.

\section{Received: 2 January 2019 Accepted: 11 April 2019}

Published online: 09 May 2019

\section{References}

Andries, N., \& Billon, S. (2016). Retail bank interest rate pass-through in the euro area: An empirical survey. Economic Systems, 40(1), 170-194.

Baumol, W. J. (1982). Contestable markets: An uprising in the theory of industry structure. American Economic Review, 72(1), $1-15$

Bernanke, B. S., \& Gertler, M. (1995). Inside the black box: The credit channel of monetary policy transmission. The Journal of Economic Perspectives, 9(4), 27-48.

Chen, H., et al. (2017). The effectiveness of monetary policy in China: Evidence from a Qual VAR. China Economic Review, 43, 216-231.

Chong, B. S. (2010). Interest rate deregulation: Monetary policy efficacy and rate rigidity. Journal of Banking \& Finance, 34(6), 1299-1307.

Ciccarone, G., et al. (2014). Incomplete interest rate pass-through under credit and labor market frictions. Economic Modelling, $36,645-657$.

Cottarelli, C., et al. (1986). Monetary policy through ceilings on bank lending. Wiley on behalf of the Centre for Economic Policy Research, Center for Economic Studies, CESifo Group, and the Maison des Sciences de l'Homme, 1(3), 673-710.

Fernald, J. G., et al. (2014). Monetary policy effectiveness in China: Evidence from a FAVAR model. Journal of International Money and Finance, 49, 83-103.

Fu, X., et al. (2014). Bank competition and financial stability in Asia Pacific. Journal of Banking \& Finance, 38(1), 64-77.

Fungáčová, Z., et al. (2016). Reserve requirements and the bank lending channel in China. Journal of Macroeconomics, 50, 37-50.

Gertler, M., \& Gilchrist, S. (1994). Monetary policy, business cycles, and the behavior of small manufacturing firms. The Quarterly Journal of Economics, 109(2), 309-340.

He, D., \& Wang, H. (2012). Dual-track interest rates and the conduct of monetary policy in China. China Economic Review, 23, 928-947.

He, Q., et al. (2013). Factor-augmented VAR analysis of the monetary policy in China. China Economic Review, 25, 88-104

Hou, X., \& Wang, Q. (2013). Implications of banking marketization for the lending channel of monetary policy transmission: Evidence from China. Journal of Macroeconomics, 38, 442-451.

Hristov, N., et al. (2014). The interest rate pass-through in the euro area during the global financial crisis. Journal of Banking \& Finance, 48, 104-119.

Jin, X. J., et al. (2014). Interest rate pass-through in a dual-track system: Evidence from China. China \&World Economy, 22(4), 21-39.

Keeley, M. C. (1990). Deposit insurance, risk, and market power in banking. The American Economic Review, 80(5), 1183-1200.

Kleimeier, S., \& Sander, H. (2006). Expected versus unexpected monetary policy impulses and interest rate pass-through in euro-zone retail banking markets. Journal of Banking \& Finance, 30(7), 1839-1870.

Koch, C. (2015). Deposit interest rate ceilings as credit supply shifters: Bank level evidence on the effects of regulation Q. Journal of Banking \& Finance, 61, 316-326. 
Kopecky, K. J., \& Van Hoose, D. D. (2012). Imperfect competition in bank retail markets, deposit and loan rate dynamics, and incomplete pass through. Journal of Money, Credit and Banking, 44(6), 1185-1205.

Kwapil, C., \& Scharler, J. (2010). Interest rate pass-through, monetary policy rules and macroeconomic stability. Journal of International Money and Finance, 29(2), 236-251.

Lam, C. H., \& Chen, A. H. (1985). Joint effects of interest rate deregulation and capital requirements on optimal bank portfolio adjustments. Wiley for the American Finance Association, 40(2), 563-575.

Liu, B., et al. (2018). Interest rate pass-through in China: An analysis of Chinese commercial banks. Emerging Markets Finance and Trade, 53(13), 3051-3063.

Liu, M.-H., \& Margaritis, D. (2014). Inflation, monetary policy and reserve requirement ratio adjustments in China. Frontiers of Business Research in China, 8(2), 137-153.

Liu, M.-H., et al. (2008). Monetary policy transparency and pass-through of retail interest rates. Journal of Banking \& Finance, $32(4), 501-511$.

Mertens, K. (2008). Deposit rate ceilings and monetary transmission in the US. Journal of Monetary Economics, 55, 1290-1302.

Mirzaei, A., et al. (2013). Does market structure matter on banks' profitability and stability? Emerging vs. advanced economies. Journal of Banking \& Finance, 37(1), 2920-2937.

Pesaran, M., et al. (2001). Bound testing approaches to the analysis of level relationships. Journal of Applied Economics, 16(3), 289-326.

Qiao, Z., \& Liu, Y. (2017). Open market operation effectiveness in China. Emerging Markets Finance and Trade, 53(8), 1706-1719.

Tabak, B. M., et al. (2012). The relationship between banking market competition and risk-taking: Do size and capitalization matter? Journal of Banking \& Finance, 36, 3366-3381.

Tobin, J. (1970). Deposit interest ceilings as a monetary control. Journal of Money, Credit and Banking, Ohio State University Press, 2(1), 4-14.

Unde, A., \& Heimeshoff, U. (2009). Consolidation in banking and financial stability in Europe: Empirical evidence. Journal of Banking \& Finance, 33, 1299-1311.

Wang, H. (2016). Incremental reform and industry politics: The historical institutionlism analysis on the transformation of banking financial form in China (1984-2015). PhD thesis, Shanghai University.

Wang, R., et al. (2017). Borrowing constraint, heterogeneous production sectors and policy implications: The case of China. International Review of Economics \& Finance, 49, 568-581.

Wong, F.-k., \& Poon, C.-c. (2011). China's monetary policy and its transmission mechanisms before and after the financial tsunami. Chinese Economy, 44(3), 84-108.

Yang, J., \& Shao, H. (2016). Impact of bank competition on the bank lending channel of monetary transmission: Evidence from China. International Review of Economics \& Finance, 43, 468-481.

\section{Submit your manuscript to a SpringerOpen ${ }^{\circ}$ journal and benefit from:}

- Convenient online submission

- Rigorous peer review

- Open access: articles freely available online

- High visibility within the field

- Retaining the copyright to your article

Submit your next manuscript at $\boldsymbol{s p r i n g e r o p e n . c o m ~}$ 